\title{
Structural and Functional Analysis of Ribosomal Subunits from Vegetative Mycelium and Spores of Streptomyces antibioticus
}

\author{
By L. M. QUIROS, ${ }^{1}$ F. PARRA,$^{2}$ C. HARDISSON ${ }^{1}$ AND J. A. SALAS ${ }^{1 *}$ \\ Departamento de Biologia Funcional (Areas de Microbiologia ${ }^{1}$ y Bioquimica ${ }^{2}$ ), \\ Universidad de Oviedo, 33006 Oviedo, Spain
}

(Received 25 August 1988; revised 4 January 1989; accepted 26 January 1989)

\begin{abstract}
The structure and function of ribosomes from spores and vegetative mycelium of Streptomyces antibioticus were compared. Differences were observed in the sedimentation coefficient of ribosomes from spores (56.86S) and vegetative mycelium (69.77S). Reverse-phase highperformance liquid chromatography of ribosomal proteins of the $30 \mathrm{~S}$ and $50 \mathrm{~S}$ subunits revealed differences which included several polypeptides present in the vegetative ribosomes but absent from spore ribosomes. The latter were also defective in their ability to promote polyphenylalanine synthesis, the functional activity of both ribosomal subunits being affected. The soluble fraction of spores also showed decreased protein-synthesizing activity, compared to that of the vegetative mycelium. Recovery of normal ribosomal subunits and soluble fraction activity occurred early in the germination process, reaching activity values approaching those of the vegetative state during initiation of germination. It is suggested that regulation of cellular metabolism at the level of translation may be involved in the establishment of spore dormancy.
\end{abstract}

\section{INTRODUCTION}

The processes of differentiation associated with bacterial sporulation and spore germination are controlled by poorly understood mechanisms. Understanding the differentiation process requires a knowledge of the machinery of macromolecular biosynthesis, since the central problem is control of the transcription of particular genes and consequent synthesis of specific proteins. In bacterial endospores, such control may be exerted during differentiation at the level of transcription (Klier et al., 1973; Losick et al., 1979) or at the level of translation (Guha \& Szulmajster, 1977; Setlow, 1981). In Streptomyces, there have been several studies on the pattern of macromolecular biosynthesis during spore germination (Hardisson et al., 1978, 1980; Hirsch \& Ensign, 1975; Mikulik et al., 1977). Protein and RNA degradation (Guijarro et al., 1982, 1983), the existence of a stable mRNA fraction in spores (Hardisson et al., 1980; Quirós et al., 1985) and some differences between the ribosomal proteins from spores and vegetative mycelium (Mikulik et al., 1984) have been reported.

In order to obtain a better understanding of the germination process, we have analysed the protein biosynthetic machinery of $S$. antibioticus spores in an attempt to discover whether regulation at the level of translation could be involved in the sporulation and spore germination processes. This paper compares the ribosomes of dormant spores and vegetative mycelium of $S$. antibioticus and shows structural and functional differences.

\section{METHODS}

Culture conditions. The micro-organism used in this study was Streptomyces antibioticus ATCC 11891. The conditions used for vegetative growth, sporulation and germination have been described previously (Hardisson $e t$ al., 1978). Spores were scraped from the agar surface with a spatula and resuspended in ice-cold deionized

Abbreviation: RP-HPLC, reverse-phase high-performance liquid chromatography. 
(Milli-Q) water. The suspension was pulsed three times ( $30 \mathrm{~s}$ each) in a $150 \mathrm{~W}$ ultrasonic disintegrator to eliminate residual fragments of mycelium, a treatment which had no effect on spores. The spores were washed twice with ice-cold deionized water and once with buffer A (see below). Germination was observed by phase-contrast microscopy, which allowed identification of the different stages of germination (Hardisson et al., 1978).

Buffers. Buffer A : $10 \mathrm{~mm}-\mathrm{HEPES} / \mathrm{KOH}, \mathrm{pH} 7.5$ at $20^{\circ} \mathrm{C} ; 10 \mathrm{~mm}-\mathrm{MgCl}_{2} ; 50 \mathrm{mM}-\mathrm{NH}_{4} \mathrm{Cl} ; 3 \mathrm{~mm}$-2-mercaptoethanol. Buffer B: $10 \mathrm{mM}-\mathrm{HEPES} / \mathrm{KOH}$, pH 7.5 at $20^{\circ} \mathrm{C} ; 30 \mathrm{mM}-\mathrm{MgCl}_{2} ; 1 \mathrm{M}-\mathrm{NH}_{4} \mathrm{Cl} ; 3 \mathrm{~mm}-2$-mercaptoethanol. Buffer C: $10 \mathrm{~mm}-\mathrm{HEPES} / \mathrm{KOH}$, pH 7.5 at $20^{\circ} \mathrm{C} ; 1 \mathrm{~mm}-\mathrm{MgCl}_{2} ; 100 \mathrm{mM}-\mathrm{KCl} ; 3 \mathrm{~mm}$-2-mercaptoethanol. Buffer D: $10 \mathrm{~mm}$-Tris/ $\mathrm{HCl}, \mathrm{pH} 8.0$ at $20^{\circ} \mathrm{C} ; 6 \mathrm{M}$-urea; $150 \mathrm{~mm}$-LiCl; $3 \mathrm{~mm}$-2-mercaptoethanol.

Preparation of ribosome and soluble fractions. Mycelia or spores were washed twice in buffer $\mathrm{A}$ and resuspended in the same buffer. Approximately $1 \mathrm{~g}$ of glass beads $(0.10-0.11 \mathrm{~mm}$ diameter) were added per ml of suspension and the mixture pulsed in a Braun model MSK mechanical homogenizer (five pulses of 1 min with intermittent cooling with dry-ice). More than $95 \%$ of the cells were broken by this treatment. The glass beads were removed and the extracts centrifuged at $30000 \mathrm{~g}$ for $30 \mathrm{~min}$ at $4{ }^{\circ} \mathrm{C}$ and the upper two-thirds of the supernatant retained (fraction S30). The S30 fraction was layered over an equal volume of buffer B containing $40 \%(\mathrm{w} / \mathrm{v}$ ) sucrose and centrifuged in a Beckman rotor 42.1 at 30000 r.p.m. $(100000 \mathrm{~g})$ overnight at $4{ }^{\circ} \mathrm{C}$. The supernatant (designated as $\left.\mathrm{S} 100^{*}\right)$ was dialysed at $4{ }^{\circ} \mathrm{C}$ against two changes of buffer $\mathrm{A}\left(500 \mathrm{ml}\right.$ each) and stored in aliquots at $-70^{\circ} \mathrm{C}$. The ribosomes were resuspended in buffer $\mathrm{A}$ and centrifuged in an Eppendorf minifuge for $30 \mathrm{~s}$ to remove contaminating membranes. The ribosomes were then centrifuged through buffer B plus sucrose and, after resuspension in buffer $\mathrm{A}$, stored in aliquots at $-70^{\circ} \mathrm{C}$.

Preparation of ribosome subunits. Ribosomes $\left(300 A_{260}\right.$ units) were diluted into $7 \mathrm{ml}$ buffer $\mathrm{C}$, dialysed against buffer $\mathrm{C}$ for $2-3 \mathrm{~h}$ at $4{ }^{\circ} \mathrm{C}$ and then layered over a sucrose density gradient $(10-30 \%$, w/v, linear concentration gradient) made up in buffer $\mathrm{C}$ and centrifuged in a Beckman zonal rotor Z-60 at 45000 r.p.m. for $3 \mathrm{~h}$ at $4{ }^{\circ} \mathrm{C}$. To recover the ribosomal subunits, buffer $\mathrm{C}$ containing $40 \%$ sucrose was pumped into the rotor edge with a peristaltic pump and fractions containing the $50 \mathrm{~S}$ and $30 \mathrm{~S}$ subunits monitored by measuring absorbance at $260 \mathrm{~nm}$ with a UV-1 (Pharmacia) single path monitor. The $\mathrm{Mg}^{2+}$ concentration in these fractions was increased to $10 \mathrm{mM}$ and the $30 \mathrm{~S}$ and $50 \mathrm{~S}$ subunits collected by sedimentation at 30000 r.p.m. $(100000 \mathrm{~g})$ overnight at $4{ }^{\circ} \mathrm{C}$. The subunits were then purified by passage through a second gradient after which they were again recovered by centrifugation, resuspended in buffer $\mathrm{A}$ and stored in aliquots at $-70^{\circ} \mathrm{C}$.

Polyuridylic-acid [poly $(U)]$ dependent protein synthesis. In vitro protein synthesis was measured as the synthesis of polyphenylalanine directed by poly(U). The reaction mixture (total volume $100 \mu \mathrm{l}$ ) contained the following: $20 \mathrm{mM}-\mathrm{HEPES} / \mathrm{KOH}, \mathrm{pH} 7.5$ at $20^{\circ} \mathrm{C} ; 10 \mathrm{~mm}-\mathrm{MgCl}_{2} ; 50 \mathrm{mM}-\mathrm{NH}_{4} \mathrm{Cl} ; 50 \mathrm{mM}-\mathrm{KCl} ; 2.5 \mathrm{~mm}-\mathrm{ATP} ; 0 \cdot 35 \mathrm{mM}-\mathrm{GTP}$; $0.8 \mu \mathrm{g}$ pyruvate kinase; $7.5 \mathrm{~mm}$-phosphoenolpyruvate; $2.6 \mu \mathrm{Ci}(96.2 \mathrm{kBq})\left[{ }^{3} \mathrm{H}\right]$ phenylalanine $(0.26 \mu \mathrm{M}) ; 1.25 \mu \mathrm{g}$ phe-specific tRNA; $50 \mu \mathrm{g}$ poly(U); $25-50 \mathrm{pmol}$ ribosomes; variable volume $(10-30 \mu \mathrm{l})$ of $\mathrm{S} 100^{*}$. Reaction mixtures were incubated at $30^{\circ} \mathrm{C}$ and samples $(10 \mu \mathrm{l})$, removed at various time intervals, were added to $1 \mathrm{ml} 5 \%$ (w/v) trichloroacetic acid (TCA). After heating at $90^{\circ} \mathrm{C}$ for $15 \mathrm{~min}$, samples were filtered through Whatman $\mathrm{GF} / \mathrm{C}$ discs $(2.5 \mathrm{~cm}$ diameter $)$, dried and the radioactivity estimated in a liquid-scintillation counter.

Preparation and analysis of ribosomal proteins. Proteins were extracted from ribosomes as described previously (Fierro et al., 1987). Samples of ribosomal subunit proteins from dormant spores or vegetative mycelium, containing $100 \mu \mathrm{g}$ protein in buffer $\mathrm{D}$, were fractionated by reverse-phase high-performance liquid chromatography (RP-HPLC) using the method of Kerlavage et al. (1983) with some minor modifications (Fierro et al., 1987). SDS-PAGE was done using $8-20 \%$ (w/v, acrylamide) gradient gel. The method used was based on that described by Laemmli (1970), with modifications (Fierro et al., 1987). The following marker proteins (Pharmacia low molecular mass kit) were used: phosphorylase b (molecular mass $94000 \mathrm{kDa}$ ), bovine serum albumin $(67000 \mathrm{kDa})$, ovalbumin $(43000 \mathrm{kDa})$, carbonic anhydrase $(30000 \mathrm{kDa})$, soybean trypsin inhibitor $(20100 \mathrm{kDa})$ and $\beta$-lactalbumin $(14400 \mathrm{kDa})$.

Determination of the number of ribosomes. At different stages of germination (as observed by phase-contrast microscopy) and in the exponential phase of vegetative growth, samples of the cultures were harvested by centrifugation, washed twice with deionized water and resuspended in $0.5 \mathrm{ml}$ deionized water. Mycelia and spores were broken using glass beads as described by Guijarro et al. (1983). More than $95 \%$ of the cells were broken and the samples were centrifuged at 5000 r.p.m. for $15 \mathrm{~min}$ at $4{ }^{\circ} \mathrm{C}$ to remove cell walls and debris. The supernatant was then centrifuged at 40000 r.p.m. for $3 \mathrm{~h}$ at $4{ }^{\circ} \mathrm{C}$. Protein and RNA concentrations in the supernatant were determined by the Lowry method and the orcinol method (Schneider, 1957), respectively. The ribosomal pellet was suspended in a small volume of deionized water and the protein and RNA content of the samples determined. The number of ribosomes per mg of cellular protein was estimated by the procedure described by Orlowski \& Sypherd (1978). Certain calculations and assumptions had to be made: (i) because the combined molecular masses of Streptomyces rRNAs are unknown; those of $E$. coli were used (i.e. $1.55 \times 10^{6}$ ); (ii) the weight of rRNA per $70 \mathrm{~S}$ ribosome was calculated by dividing the molecular mass of rRNA by Avogadro's number, giving a value of $2.57 \times 10^{-18} \mathrm{~g}$ per ribosome. Using these values and those calculated by RNA and protein determinations, the approximate number of ribosomes per $\mathrm{mg}$ of protein was calculated. 
Chemicals. Pyruvate kinase, HEPES, GTP, 2-mercaptoethanol, poly(U) and phosphoenolpyruvate were from Sigma; ATP and phe-specific tRNA were from Boehringer Mannheim; $\mathrm{KCl}, \mathrm{NH}_{4} \mathrm{Cl}$ and $\mathrm{MgCl}_{2}$ were from Merck; L- $\left[2,3,4,5,6-{ }^{3} \mathrm{H}\right]$ phenylalanine [specific activity $\left.101 \mathrm{Ci} \mathrm{mmol}^{-1}\left(3 \cdot 73 \mathrm{TBq}^{\mathrm{mmol}}{ }^{-1}\right)\right]$ was from Amersham. All other reagents were of analytical grade.

\section{RESULTS}

\section{Isolation of ribosomes}

Ribosomes isolated from the vegetative mycelium of $S$. antibioticus appeared typically as a transparent sediment after ultracentrifugation. However, spore ribosomes obtained in the same way (i.e. after washing in a high-salt buffer plus sucrose) bound a brown pigment. The pigment could not be removed from ribosomes by either successive additional washings in high-salt buffer (buffer B) or after extensive dialysis. However, pigment-free spore ribosomes could be obtained as follows: after high-salt washing the ribosomes were centrifuged in a $10-40 \%$ sucrose density gradient in the same buffer for $60 \mathrm{~min}$ at 45000 r.p.m. in a Beckman zonal rotor. A peak of clean and transparent ribosomes was detected while some of the ribosomes sedimented to the bottom of the tube together with the pigment, probably due to the formation of ribosomal aggregates. Interestingly, freezing at $-70^{\circ} \mathrm{C}$ somehow prevented removal of the pigment by this method. The identity of the pigment is not known but it absorbed in the visible range, was not soluble in organic solvents, bound more tightly to ribosomal RNA than to ribosomal proteins (i.e. was extracted together with RNA by glacial acetic acid) and did not give a positive reaction with the Folin phenol reagent.

Differences were also observed in the sedimentation coefficients of ribosomes from spores (pigment-free) and vegetative mycelium. Thus, when both types of ribosomes were centrifuged through a linear sucrose gradient, two different peaks were detected, with the one corresponding to spore ribosomes moving more slowly. Estimations of the sedimentation coefficients gave values of $69.77 \mathrm{~S}$ (approx.) and 56.86S (approximately) for mycelial and spore ribosomes, respectively.

\section{Changes in the absolute ribosome content during spore germination}

We made some estimations of the number of ribosomes per mg of cellular protein at different stages of germination (dormant spores, dark spores and swollen spores) and in the vegetative mycelium (Table 1). Early in the germination process (dark spores), the number of ribosomes increased twofold compared to the number in dormant spores. Swollen spores gave the highest value for the number of ribosomes (about 3.5 times the value for dormant spores), which was higher than that found in the vegetative mycelium. This result is in accordance with increased biosynthetic activity during spore swelling (Hardisson et al., 1978, 1980).

\section{Translation of poly $(U)$ by ribosomes}

The ability of the ribosomes of dormant spores and vegetative mycelium of $S$. antibioticus to synthesize protein was compared by assaying their ability to incorporate $\left[{ }^{3} \mathrm{H}\right]$ phenylalanine into polypeptides as directed by the synthetic messenger RNA poly(U). Early experiments (data not given) showed that pigment-bound ribosomes of dormant spores had almost negligible activity. However, when we used pigment-free ribosomes from dormant spores, we could detect proteinsynthesizing activity which represented about $24 \%$ of that observed with vegetative mycelium ribosomes (Tables 2). The protein-synthesizing activity of the ribosomes of both dormant spores and vegetative mycelium was proportional to the ribosome concentration in the range 10 to 50 pmols of ribosomes. The low activity detected with spore ribosomes was only observed using the soluble fraction $\left(\mathrm{S} 100^{*}\right)$ of the mycelium, with virtually no activity when the spore $\mathrm{S} 100^{*}$ was used. Similarly, mycelial $70 \mathrm{~S}$ ribosomes were only active when combined with homologous S100* and were unable to synthesize polyphenylalanine in the presence of spore S100* (Table 2). These results suggest that dormant spores of $S$. antibioticus have both ribosome and $S 100^{*}$ fractions that are defective in their ability to translate poly(U).

To determine whether or not the low ribosomal activity was subunit-mediated, the activity of 
Table 1. Number of ribosomes present during spore germination and vegetative growth

The values were obtained as described in Methods. Each value in the Table is the mean of six independent determinations.

$\begin{array}{lc} & 10^{-13} \times \text { No. of ribosomes } \\ \text { Stage } & \text { per mg of protein } \\ \text { Dormant spores } & 8.14 \\ \text { Dark spores } & 15.12 \\ \text { Swollen spores } & 29.09 \\ \text { Mycelium } & 22.59\end{array}$

Table 2. Poly $(U)$-dependent protein-synthesis activity of the soluble fractions of spores and mycelium

Each assay contained $50 \mathrm{pmol}$ of ribosomes. Values are the mean of three independent determinations $\pm \mathrm{SD}$ for the incubation for incorporation of $\left[{ }^{3} \mathrm{H}\right]$ phenylalanine into TCA-insoluble material after incubation for $45 \mathrm{~min}$ at $30^{\circ} \mathrm{C}$.

\begin{tabular}{|c|c|c|}
\hline $\mathrm{S} 100^{*}$ & $70 \mathrm{~S}$ & $\begin{array}{c}0^{3} \times\left[{ }^{3} \mathrm{H}\right] \text { Phenylalanine } \\
\text { incorporation }(\mathrm{pmol})\end{array}$ \\
\hline Mycelium & Mycelium & $142 \pm 70$ \\
\hline Mycelium & Spores & $34 \pm 20$ \\
\hline Spores & Mycelium & $5 \pm 1$ \\
\hline Spores & Spores & $2 \pm 1$ \\
\hline
\end{tabular}

the system was tested using purified ribosomal subunits of dormant spores and mycelium in homologous and heterologous combinations. Subunits were separated in a sucrose-density gradient with a low $\mathrm{Mg}^{2+}$ concentration and repurified through a second gradient. In either case ( $30 \mathrm{~S}$ and $50 \mathrm{~S}$ subunits), no contamination by the other subunit was detected and this was confirmed by the absence of activity of each separated subunit preparation (data not shown). Homologous re-association experiments were done with these subunits and it was observed that, while the total initial $70 \mathrm{~S}$ ribosomal activity was recovered when mycelial ribosomal subunits were mixed, only about $50 \%$ recovery was obtained with spore ribosomal subunits (Table 3 ). When re-association was done in a heterologous manner, the results showed (Table 3) that both ribosomal subunits of dormant spores contributed to the decreased activity of spore ribosomes. However, it was the 50S subunit which gave the lowest values of activity in heterologous combinations.

We tested the possibility that during spore germination, the normal activity of the proteinsynthesizing system was recovered. The $S 100^{*}$ fraction and ribosomes were obtained from dormant and germinating spores (15 and $60 \mathrm{~min}$ incubation) and their ability to synthesize polyphenylalanine determined. After $15 \mathrm{~min}$ of germination, the activity of the translation system clearly increased, and much of the vegetative activity (approximately $70 \%$ ) was recovered after about $60 \mathrm{~min}$ of germination (Table 4).

In order to determine if the recovery in activity was due to the soluble fraction or to the ribosomes (or both), experiments were done in which heterologous combinations were made between the soluble fractions and ribosomes. The results showed that approximately $90 \%$ of the normal activity of the ribosomes and of the soluble fraction was recovered after $60 \mathrm{~min}$ of germination (Table 4).

\section{Analysis of the ribosomal proteins of dormant spores and vegetative mycelium}

In an attempt to explain the functional changes accompanying the transition from dormant spores into vegetative cells, we investigated the protein composition of both types of ribosomes to detect possible structural changes. The simple analysis by SDS-PAGE of purified 50S and 30S ribosomal subunits clearly showed some of the major differences between subunits (Fig. 2, lanes 


\section{Table 3. Poly $(U)$-dependent protein synthesis activity of reconstituted ribosomes}

The assays contained $50 \mathrm{pmol}$ of $70 \mathrm{~S}$ ribosomes or of each ribosomal subunit and the soluble fraction $\left(\mathrm{S} 100^{*}\right)$ was that from vegetative mycelium. Values represent the mean of three independent determinations \pm SD for the incorporation of $\left[{ }^{3} \mathrm{H}\right]$ phenylalanine into TCA-insoluble material after incubation for $4 \overline{5} \mathrm{~min}$ at $30^{\circ} \mathrm{C}$.

$\begin{array}{cccc}\overbrace{30 S} & \text { Source of subunits: } & 70 \mathrm{~S} & \begin{array}{c}10^{3} \times\left[{ }^{3} \mathrm{H}\right] \text { phenylalanine } \\ \text { incorporation (pmol) }\end{array} \\ - & - & \text { Mycelium } & 1350 \pm 60 \\ - & - & \text { Spores } & 270 \pm 10 \\ \text { Mycelium } & \text { Mycelium } & - & 1510 \pm 60 \\ \text { Mycelium } & \text { Spores } & - & 270 \pm 20 \\ \text { Spores } & \text { Mycelium } & - & 780 \pm 40 \\ \text { Spores } & \text { Spores } & - & 140 \pm 8\end{array}$

Table 4. Protein-synthesis activity of the soluble fraction and 705 ribosomes during spore germination and vegetative growth

Each assay contained $50 \mathrm{pmol}$ of ribosomes. Values represent the mean of three independent determinations \pm SD for the incorporation of $\left[{ }^{3} \mathrm{H}\right]$ phenylalanine into TCA-insoluble material after incubation for $45 \mathrm{~min}$ at $30^{\circ} \mathrm{C}$. Abbreviations: DS, dormant spores; VM, vegetative mycelium; GS (15), germinating spores, 15 min of germination; GS (60), germinating spores, 60 min of germination.

$\begin{array}{llc}\text { S100* } & \text { Ribosomes } & \begin{array}{r}10^{3} \times\left[{ }^{3} \mathrm{H}\right] \text { Phenylalanine } \\ \text { incorporation (pmol) }\end{array} \\ \text { DS } & \text { DS } & 2 \pm 0.06 \\ \text { VM } & \text { DS } & 310 \pm 10 \\ \text { DS } & \text { VM } & 2 \pm 0.02 \\ \text { GS (15) } & \text { GS (15) } & 100 \pm 7 \\ \text { VM } & \text { GS (15) } & 630 \pm 20 \\ \text { GS (15) } & \text { VM } & 550 \pm 30 \\ \text { GS (60) } & \text { GS (60) } & 1010 \pm 50 \\ \text { VM } & \text { GS (60) } & 1210 \pm 40 \\ \text { GS (60) } & \text { VM } & 1280 \pm 40 \\ \text { VM } & \text { VM } & 1420 \pm 80\end{array}$

1 and 2; Fig. 4, lanes 1 and 2). Several protein bands observed in the ribosome subunits from mycelium were absent in the homologous subunit from spores. In addition, some changes in band intensity were observed and proteins occasionally detected in spores were absent in vegetative mycelium. The RP-HPLC analysis of purified ribosome subunits from spores and mycelium gave a clearer picture of the differences. When the protein pattern of the $50 \mathrm{~S}$ ribosome subunits from spore and mycelial ribosomes was compared (Fig. $1 a$ and $1 b$, respectively), at least nine different peaks which were only present or were larger in the mycelial 50S subunit were detected (Fig. $1 a$, peaks A to I). In contrast, only one peak present in the $50 \mathrm{~S}$ subunit from spores was absent from the homologous mycelial subunit (Fig. $1 b$, peak J) and found to be a single protein species (Fig. 2, lane J). The differential peaks were analysed by SDS-PAGE and showed a single protein band (Fig. 2, lanes A, C, D, E, H, I and J), or two different proteins (Fig. 2 , lanes $B, F$ and $G)$. It must be emphasized that similar amounts of protein $(100 \mu \mathrm{g})$ were applied to the RP-HPLC column and the SDS-PAGE gels and differences in peak height can therefore not be attributed to variations in the amount of protein analysed.

The interpretation of results obtained by RP-HPLC analysis of spore and mycelial $30 \mathrm{~S}$ subunits (Fig. $3 a$ and $3 b$, respectively) is more complex. Three peaks present in the mycelial $30 \mathrm{~S}$ subunits (Fig. $3 a$, peaks L, M and Q) were absent from the homologous spore subunit and, when analysed by SDS-PAGE, were each found to contain a unique protein species (Fig. 4, lanes L, M and Q). In contrast, only one peak present in the $30 \mathrm{~S}$ subunit from spores (Fig. 3, peak V) was 


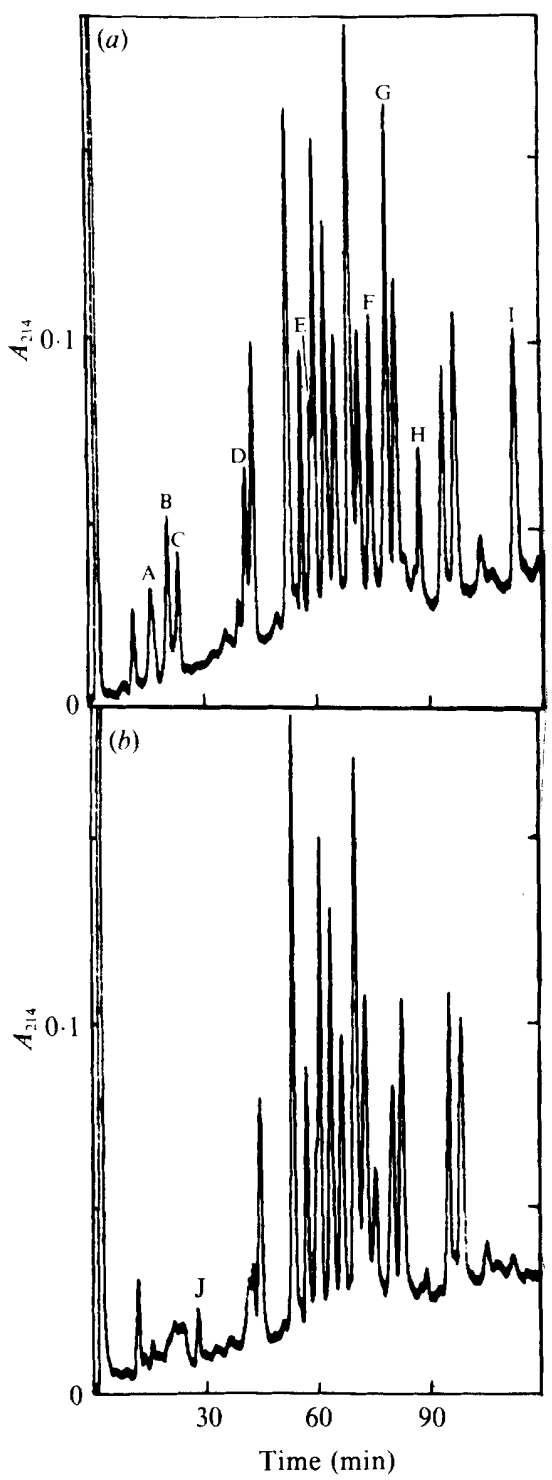

Fig. 1

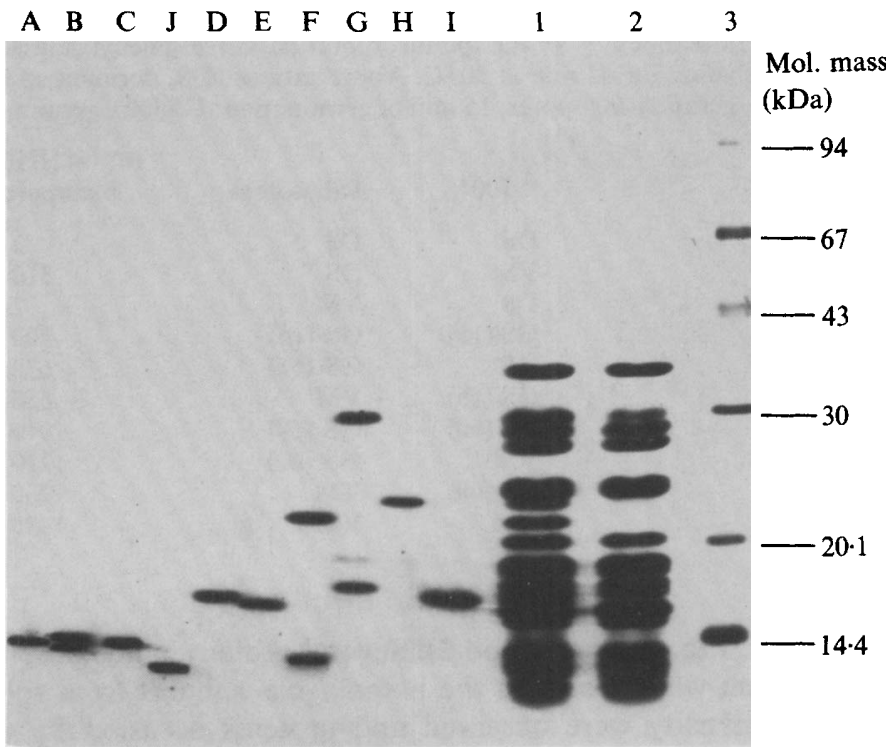

Fig. 2

Fig. 1. RP-HPLC chromatograms of $50 \mathrm{~S}$ ribosomal subunit proteins. (a) Vegetative mycelium; (b) spores. Peaks labelled A to I were only present or larger in the vegetative 50 S subunits whereas peak $\mathrm{J}$ was only detected in the spore subunits. The chromatographic conditions are described in Methods.

Fig. 2. SDS-PAGE of differential 50S ribosomal subunit proteins from Fig. 1. Freeze-dried RP-HPLC fractions or total $50 \mathrm{~S}$ proteins were analysed in an $8-20 \%(\mathrm{w} / \mathrm{v})$ polyacrylamide gradient as described in Methods. Lanes A to I in the gel correspond to the same peaks in Fig. 1. Lanes 1 and 2, total $50 \mathrm{~S}$ ribosomal proteins from vegetative mycelium and spores, respectively; lane 3, molecular mass markers (see Methods).

not detected in vegetative ribosomes and only one single protein species was present (Fig. 4, lane $\mathrm{V})$. The remaining differences in the RP-HPLC patterns were changes in peak height, which can be mostly explained by the presence of extra proteins in the mycelial subunits under the same chromatographic peak (Fig. 4, lanes $\mathrm{O}$ and $\mathrm{P}$ ) or differences in the concentration of individual proteins (Fig. 4, lanes $K$ and $S$ ). 


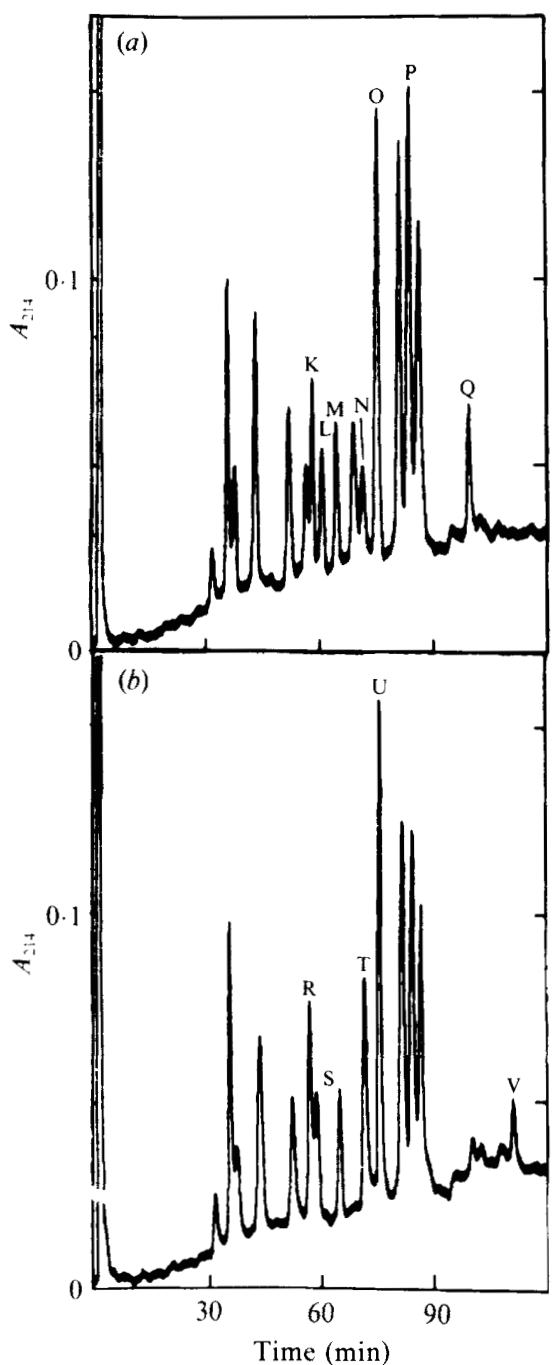

Fig. 3

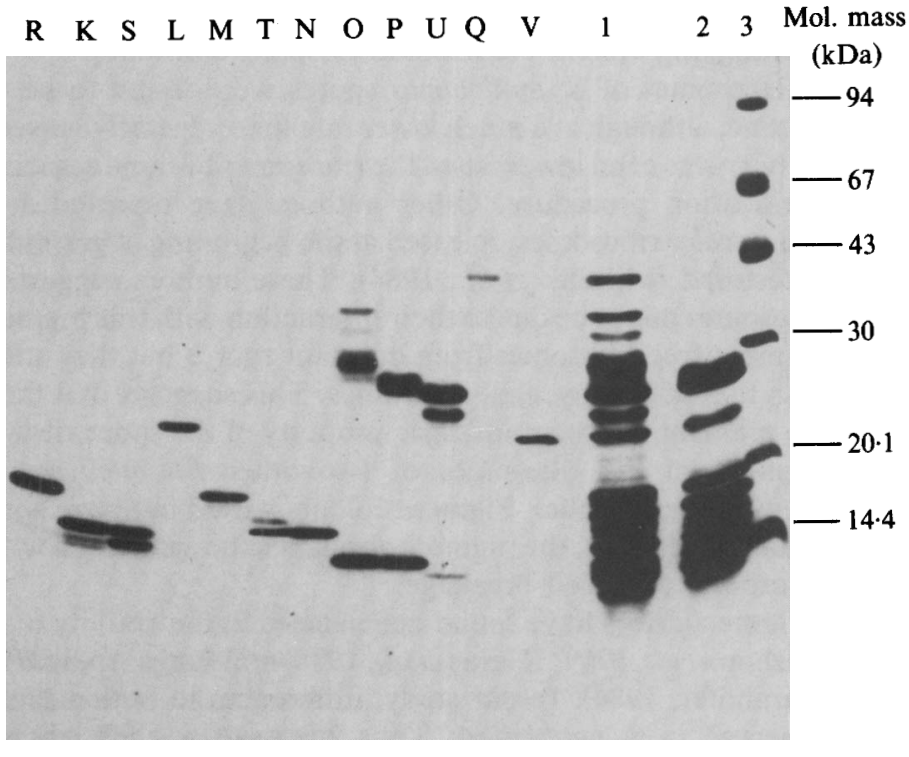

Fig. 4

Fig. 3. RP-HPLC chromatograms of $30 \mathrm{~S}$ ribosomal subunit proteins. (a) Vegetative mycelium; (b) spores. Peaks labelled $\mathrm{K}$ to $\mathrm{Q}$ (vegetative subunits) and R to V (spore subunits) show the differences between the subunits.

Fig. 4. SDS-PAGE of differential 30 S ribosomal subunit proteins from Fig. 3. Freeze-dried RP-HPLC fractions or total $30 \mathrm{~S}$ proteins were analysed in an $8-20 \%$ polyacrylamide gradient as described in Methods. Lanes $\mathrm{R}$ to $\mathrm{V}$ in the gel correspond to the same peaks in Fig. 3. Lanes 1 and 2, total $30 \mathrm{~S}$ ribosomal proteins from vegetative mycelium and spores, respectively; lane 3 , molecular mass markers (see Methods).

In order to exclude the possibility that proteolysis could be responsible for these structural differences, the following experiments were done. Firstly, ribosomes from both developmental stages were isolated in the presence of protease inhibitors (o-phenanthroline, PMSF and EDTA, all at $1 \mathrm{~mm}$ final concentration) throughout the isolation procedure. These three compounds inhibit more than $95 \%$ of the spore protease activity (Guijarro et al., 1983). No significant differences (data not shown) were detected in the presence or absence of these protease inhibitors. In the second control experiments, spores and vegetative mycelium were mixed at a $1: 1$ dry weight ratio and ribosomes isolated and analysed by RP-HPLC. If observed differences 
between spores and vegetative mycelium were caused by proteolysis, it would be expected that this 'mixed ribosomal population' would give the RP-HPLC protein pattern of spore ribosomes due to spore proteases acting on the mycelial ribosomes proteins. Addition of both types of patterns was obtained, and similar results were obtained with purified ribosomal subunits (data not shown). Therefore, we can conclude that the structural differences detected between spore and mycelium ribosomes are not due to proteolysis during the isolation of ribosomes.

\section{DISCUSSION}

The initiation of protein biosynthesis during spore germination of different Streptomyces species differs with respect to the lag period before biosynthesis begins. In most of the species studied, the lag period was short (Ensign, 1978; Hardisson et al., 1980; Mikulik et al., 1977, 1984) but in one case there was a long delay before synthesis of macromolecules commenced (Nagatsu \& Matsuyama, 1970). In S. antibioticus, protein biosynthesis was detected after $5 \mathrm{~min}$ of germination and the rate increased rapidly in the first hour of germination (Hardisson et al., 1980). The study reported here aimed to determine whether some defects in the spore proteinsynthesizing system contributed to spore dormancy.

Ribosomes of $S$. antibioticus spores were found to be capable of synthesizing polyphenylalanine, although at a much lower rate than vegetative mycelium ribosomes. The spore ribosome activity was even lower when the ribosomes became associated with a brown pigment during the purification procedure. Other authors have reported a similar dark pigment bound to $S$. granaticolor ribosomes, released at the beginning of germination when normal ribosome activity is restored (Mikulik et al., 1984). These authors suggested that the low activity of the spore ribosomes might be due to their interaction with this pigment. In S. antibioticus, we could obtain pigment-free ribosomes from dormant spores but they still showed low activity in comparison with that of the mycelial ribosomes. This suggests that the low ribosomal activity is not due to the pigment but to an intrinsic property of the spore ribosomes. We have also observed bound pigment in the ribosomes of two other Streptomyces species (S. griseus and S. scabies) (unpublished results). Pigment colours varied but were similar to the colour of harvested intact spores. Therefore, the pigment appears to be associated with the spore integuments and binds to ribosomes after cell breakage.

Some authors have found deficiencies in the activity of the ribosomes of Bacillus endospores (Bishop et al., 1969; Kieras et al., 1978) and fungal spores (Horikoshi \& Ikeda, 1968; Jaworski \& Stumhofer, 1984). In our study, differences in both structure and function of ribosomes were observed in S. antibioticus. Thus, high-salt washed ribosomes of dormant spores exhibited a different sedimentation coefficient than vegetative ribosomes, probably explained by the detection by RP-HPLC and SDS-PAGE of several differences in the ribosomal protein patterns. The involvement of rRNA breakdown in the low spore ribosomal activity can not be completely excluded but because we were able to isolate undegraded rRNA from both developmental stages (data not shown), gross degradation of rRNA cannot be main cause of ribosome inactivity. The differences observed in protein patterns were mainly caused by the presence of polypeptides in the vegetative ribosomes which were absent in the spore ribosomes. The results of control experiments excluded the possibility that such differences are due to proteolysis. Interestingly, when spore ribosome subunits were reconstituted, recovery of proteinsynthesizing activity was only approximately $50 \%$, whereas all of the mycelial ribosome activity could be recovered in this way. This suggests that some of the proteins absent from spore subunits are located in regions of interaction between the subunits.

Heterologous cross-over experiments between spore and mycelium ribosome subunits also showed differences in the activity of the $30 \mathrm{~S}$ and $50 \mathrm{~S}$ spore ribosomal subunits. However, the contribution of the large subunit to the low activity was greater, suggesting that the ribosomal functions present in this subunit are more affected. Specific alteration of the $30 \mathrm{~S}$ ribosomal subunit has also been reported during sporulation of Bacillus subtilis (Guha \& Szulmajster, 1977). Two different hypotheses may explain the low activity of spore ribosomes. (i) A fraction of the spore ribosomes could be totally inactive with the remainder being completely functional. (ii) 
The entire spore ribosomal population could be defective to a similar extent. We believe that the latter possibility is more plausible, since if only a fraction of the spore ribosomes was defective, a complete set of ribosomal proteins would have been detected in the RP-HPLC and SDS-PAGE analysis. Furthermore, this would imply that only quantitative differences would be observed while our data showed both qualitative and quantitative variations in the protein patterns of the $30 \mathrm{~S}$ and $50 \mathrm{~S}$ subunits between both developmental stages.

We have also shown that the soluble fraction $\left(\mathrm{S} 100^{*}\right)$ of $S$. antibioticus spores possessed a decreased protein-synthesizing activity when combined with ribosomes either from spores or from vegetative mycelium. Whether this defect is due to aminoacyl-tRNA synthetases or to elongation factors will require further studies.

Recovery of the normal activity of the ribosomal subunits and the soluble fraction occurs early in the germination process. We do not know if this recovery in the ribosomal activity is due to the presence of newly synthesized ribosomes or to the reactivation of pre-existing ribosomes, through biosynthesis of the missing proteins and their incorporation into the defective ribosomes. The structural and functional differences in ribosomes suggest that transition from the dormant to the vegetative state is a very complex process.

\section{REFERENCES}

Bishop, H. L., Migita, L. K. \& Doi, R. H. (1969). Peptide synthesis by extracts from Bacillus subtilis. Journal of Bacteriology 99, 771-778.

ENSIGN, J. C. (1978). Formation, properties and germination of Actinomycete spores. Annual Review of Microbiology 32, 185-219.

Fierro, J. F., Parra, F., Quirós, L. M., Hardisson, C. \& Salas, J. A. (1987). Heterogeneity of the ribosomal protein pattern in mycelium of Streptomyces species. FEMS Microbiology Letters 41, 283287.

GuHa, S. \& SzulmajsTer, J. (1977). Specific alteration of the $30 \mathrm{~S}$ ribosomal subunits of Bacillus subtilis during sporulation. Journal of Bacteriology 131, 866871.

Guijarro, J. A., Suárez, J. E., Salas, J. A. \& HARDisson, C. (1982). Characterization of RNA species synthesized during germination and vegetative growth of Streptomyces antibioticus. FEMS Microbiology Letters 14, 205-209.

Guijarro, J. A., Suárez, J. E., Salas, J. A. \& Hardisson, C. (1983). Pattern of protein degradation during germination of Streptomyces antibioticus spores. Canadian Journal of Microbiology 29, 637643.

Hardisson, C., Manzanal, M. B., Salas, J. A. \& SuÁrez, J. E. (1978). Fine structure, physiology and biochemistry of arthrospore germination in Streptomyces antibioticus. Journal of General Microbiology 105, 203-214.

Hardisson, C., Salas, J. A., Guijarro, J. A. \& SuÁrez, J. E. (1980). Macromolecular synthesis during the germination of Streptomyces spores in a chemically defined medium. FEMS Microbiology Letters 7, 233-235.

HiRsCH, C. F. \& ENSIGN, J. C. (1975). Germination of Streptomyces viridochromogenes spores. In Spores VI, pp. 28-35. Edited by P. Gerhardt, R. N. Costilow \& H. L. Sadoff. Washington, DC: American Society for Microbiology.

HorikoshI, K. \& IKedA, Y. (1968). Studies on the conidia of Aspergillus oryzae. VI. Development of protein synthesizing activity during germination. Biochimica et biophysica acta 166, 505-511.

JAworski, A. J. \& Stumhofer, P. (1984). Dormant ribosomes of Blastocladiella emersonii zoospores are arrested at elongation. Experimental Mycology 8, 1324.

Kerlavage, A. R., Hasan, T. \& Cooperman, B. S. (1983). Reverse phase high performance liquid chromatography of Escherichia coli ribosomal proteins: standardization of $70 \mathrm{~S}, 50 \mathrm{~S}$ and $30 \mathrm{~S}$ protein chromatograms. Journal of Biological Chemistry 258, 6313-6318.

Kieras, R. M., Preston, R. A. \& Douthit, H. A. (1978). Isolation of stable ribosomal subunits from spores of Bacillus cereus. Journal of Bacteriology 136, 209-218.

Klier, A. F., Lecadet, M. M. \& Dedonder, R. (1973). Sequential modifications of DNA-dependent RNA polymerase during sporogenesis in Bacillus thuringiensis. European Journal of Biochemistry 36, 317-327.

LAEMMLI, U. K. (1970). Cleavage of structural proteins during the assembly of the head of bacteriophage T4. Nature London 277, 680-685.

Losick, R., Shorentein, R. G. \& Sonenshein, A. L. (1970). Structural alteration of RNA polymerase during sporulation. Nature, London 277, 910 913.

Mikulik, K., Janda, I., Maskova, H., Statsna, J. \& JiRANOVA, A. (1977). Macromolecular synthesis accompanying the transition from spores to vegetative forms of Streptomyces granaticolor. Folia microbiologica 22, 252-261.

Mikulik, K., Janda, I., Weiser, J., Statsna, J. \& JiRANOVA, A. (1984). RNA and ribosomal protein patterns during aerial spore germination in Streptomyces granaticolor. European Journal of Biochemistry 145, 381-388.

Nagatsu, C. \& Matsuyama, A. (1970). Changes in radiosensitivity of Streptomyces cacoi spores during germination. Agricultural and Biological Chemistry 34, 860-869. 
ORLOWSKI, M. \& SYPHERD, P. S. (1978). Regulation of macromolecular synthesis during hyphal germ tube emergence from Mucor racemosus. Journal of Bacteriology 134, 76-83.

Quirós, L. M., Hardisson, C. \& Salas, J. A. (1985). Stable mRNA is a common feature of some Streptomyces spores. FEMS Microbiology Letters 26, 323-327.
SCHNEIDER, W. C. (1957). Determination of nucleic acids in tissues by pentose analysis. Methods in Enzymology 3, 680-689.

SETLOw, P. (1981). Biochemistry of bacterial forespore development and spore germination. In Sporulation and Germination, pp. 13-28. Edited by H. S. Levison, A. L. Sonenshein \& D. J. Tipper. Washington, DC: American Society for Microbiology. 